\title{
PENGARUH STRUKTUR MODAL, PROFITABILITAS, DAN STRUKTUR AKTIVA TERHADAP HARGA SAHAM
}

\author{
Sellytyanengsih E Churcill ${ }^{1}$ dan Kenny Ardillah $^{2}$
}

\author{
Fakultas Ekonomi dan Bisnis, Universitas Bunda Mulia ${ }^{1}$ \\ Fakultas Ekonomi, Bisnis, dan Ilmu Sosial, Universitas Matana ${ }^{2}$ \\ Email : kenny.ardillah@matanauniversity.ac.id
}

\begin{abstract}
The purpose of this research is to examine the influence of profitability, capital structure, and asset structure positively to the stock price on manufacture companies which are listed in Indonesia Stock Exchange (IDX). The research samples have been selected by using purposive sampling technique to the 62 manufacture companies have been published the financial statement and active stocks which have been traded at Indonesia Stock Exchange (IDX) in 2014 - 2016 periods with the amount of 186 data which have yet to be the research sample criteria.

The data analysis has been carried out by using multiple linier regressions analysis. The results of the study found out that capital structure has a positive influence on stock price means that the high capital structure influences shareholder decisions in increasing stock price. Profitability has a significant positive influence on stock price means that every increase in the profitability of a food and beverages company, it causes the stock price will increase. And asset structure have a positive influence on stock price means to indicate that every increase in asset structure of manufacture company, it causes that stock price will increase.
\end{abstract}

Keywords: Capital Structure, Profitability, Asset Structure, Stock Price.

\section{Pendahuluan}

Pada era globalisasi perkembangan dunia bisnis saat ini sangatlah pesat. Hal tersebut dapat dilihat dari semakin banyaknya perusahaan pesaing yang memiliki keunggulan kompetitif. Dengan banyaknya pesaing bisnis akan mengakibatkan banyak perusahaan membutuhkan tambahan dana untuk lebih mengembangkan perusahaannya. Salah satu sumber dana ini bisa didapatkan melalui pasar modal. Pasar modal dapat digunakan sebagai sarana mencari tambahan modal untuk memperbaiki struktur permodalan disuatu perusahaan. Perusahaan yang sudah masuk kedalam pasar modal akan lebih dikenal oleh publik, hal itu akan lebih mudah untuk mencari hubungan relasi bisnis dengan perusahaan lain. Keberhasilan pengelolahan perusahaan yang menjadi salah satu indikator adalah harga saham. Perusahaan dikatakan berhasil mengelolah usahanya, jika harga sahamnya terus mengalami peningkatan maka investor akan dapat menilai bahwa perusahaan tersebut berhasil dalam mengelola perusahaannya. Kepercayaan investor sangat dibutuhkan bagi perusahaan karena semakin banyak investor yang percaya terhadap perusahaannya maka keinginan untuk berinvestasi pada perusahaan tersebut akan semakin kuat (Indrawati dan Suprihhadi, 2016).

Kinerja Indeks Harga Saham Gabungan (IHSG) menjadi patokan dalam menentukan kinerja saham di Indonesia. Berdasarkan CNBC (2018), pada akhir tahun 2018, kinerja IHSG 
menjadi yang terburuk dalam 3 tahun terakhir setelah minus 2,54\% dalam setahun jika dibandingkan pada tahun 2017 dan 2016 yang mana IHSG masih memberikan return 19,99\% dan 15,32\%. Penurunan indeks pada akhir 2018 masih lebih baik ketimbang tahun 2015 yang minus $12,13 \%$ dan kinerja terparah 10 tahun lalu yakni tahun 2008 yang terkoreksi hingga 50,64\%. Penurunan indeks selama tahun 2018 tak bisa dilepaskan dari sejumlah katalis negatif baik dari dalam negeri seperti pertumbuhan ekonomi Indonesia yang belum beranjak dari 5\%, depresiasi nilai tukar rupiah, defisit neraca perdagangan, hingga sentimen luar negeri seperti perang dagang dan kenaikan Fed Funds Rate (FFR) bank sentral AS. Namun kinerja IHSG masih lebih baik dibandingkan dengan performa indeks bursa lain di dunia, seperti Hang Seng (Hong Kong) yang minus hingga 15,30\%, Straits Times (Singapura) minus 10,62, Nikkei (Jepang) minus 14,85\%. Adapun indeks global lain juga minus yakni Dow Jones (AS) minus 7,10\% dan FTSE (Inggris) minus 12,05\%.

Teori struktur modal menjelaskan apakah kebijakan pembelanjaan jangka panjang dapat mempengaruhi nilai suatu perusahaan yang berdampak pada harga suatu perusahaan. Kebijakan pembelanjaan suatu perusahaan dapat berpengaruh pada faktor - faktor tersebut, dan bagaimana perpaduan antara utang jangka pendek dan modal sendiri yang dapat memaksimumkan harga saham perusahaan dan meminimumkan biaya modal. Pendanaan yang efisien akan terjadi bila perusahaan mempunyai struktur modal yang optimal. Struktur modal yang optimal dapat di artikan sebagai struktur modal yang dapat meminimalkan biaya penggunaan modal keseluruhan atau biaya modal rata-rata (Harjito dan Martono, 2011:240). Perubahan struktur modal berasal dari penerbitan obligasi dan pembelian kembali saham biasa atau penerbitan saham baru (Lailia dan Suhermin, 2017).

Salah satu yang menjadi tujuan suatu perusahaan adalah menghasilkan laba (profit). Profitabilitas merupakan kemampuan yang dilakukan perusahaan untuk menghasilkan profit atau laba selama satu tahun yang dinyatakan dalam rasio laba operasi dengan penjualan dari data laporan laba rugi akhir tahun. Perusahaan dengan tingkat profitabilitas yang tinggi tentunya memiliki kesempatan untuk berekspansi atau mengembangkan usahanya untuk memperoleh laba yang lebih tinggi lagi (Putrawan et al, 2015). Rasio profitabilitas merupakan sekelompok rasio yang merupakan kombinasi dari likuiditas, manajemen aset, dan utang pada hasil operasi (Brigham dan Houston, 2010: 146). Keputusan pendanaan yang dilakukan secara tidak cermat akan menimbulkan biaya tetap dalam bentuk biaya modal yang tinggi, yang selanjutnya dapat berakibat pada rendahnya profitabilitas perusahaan (Kartini dan Arianto, 2008). ROA adalah salah satu rasio profitabilitas yang menunjukkan kemampuan perusahaan dalam memperoleh laba dari kekayaan atau aktiva yang digunakan. ROA menunjukkan seberapa besar kemampuan perusahaan menghasilkan laba yang tersedia bagi para pemegang saham biasa dengan seluruh aktiva yang dimilikinya (Purnamawati, 2016).

Selain profitabilitas, tingkat kesehatan perusahaan juga dapat diukur dari struktur aktiva di perusahaan tersebut. Struktur aktiva adalah kekayaan atau sumber-sumber ekonomi yang dimiliki oleh perusahaan yang diharapkan akan memberikan manfaat dimasa yang akan datang yang terdiri dari aktiva tetap, aktiva tidak berwujud, aktiva lancar, dan aktiva tidak lancar (Titman dan Wessels, 1988 dalam Mahapsari dan Taman, 2013).

Harga saham merupakan salah satu indikator keberhasilan pengelolaan perusahaan dan sangatlah dipengaruhi oleh kekuatan pasar itu sendiri, harga saham sifatnya berubah ubah atau berfluktuasi setiap saat dan selalu mengalami pasang surut tergantung oleh banyaknya penawaran dan permintaan atas saham tersebut serta beberapa faktor lain yang mempengaruhinya. Harga Saham menentukan adanya permintaan dan penawaran (demand and supply) terhadap jumlah lembaran saham, jika harga saham dinilai terlalu mahal (overvalued) atau terlalu rendah (undervalued) dengan kata lain salah harga 
(mispriced) oleh para investor maka permintaan terhadap saham tersebut akan turun dan kepemilikan saham menjadi terbatas bagi investor tertentu saja.

Menurut Purnamawati (2016), struktur modal perusahaan adalah kombinasi dari saham biasa dan saham preferen atau bauran seluruh sumber pendaan jangka panjang (ekuitas dan hutang) yang digunakan. Struktur modal mengacu pada sumber pendanaan perusahaan. Pendanaan dapat diperoleh dari modal ekuitas yang relative permanen hingga sumber pendanaan jangka pendek sementara yang lebih beresiko. Struktur modal merupakan pendanaan ekuitas dan utang pada suatu perusahaan yang sering dihitung berdasarkan besaran relatif berbagai sumber pendanaan.

Menurut Mahapsari dan Taman (2013) dalam hasil penelitiannya menunjukkan terdapat pengaruh positif profitabilitas terhadap harga saham. Tidak terdapat pengaruh positif struktur aktiva terhadap harga saham. Terdapat pengaruh negatif struktur modal terhadap harga saham. Hasil penelitian Lailia dan Suhermin (2017) menyatakan bahwa struktur modal berpengaruh positif dan signifikan terhadap harga saham dan profitabilitas berpengaruh positif dan signifikan terhadap harga saham.

Tujuan dilakukannya penelitian ini adalah menganalisis pengaruh positif profitabilitas, struktur modal, dan struktur aktiva terhadap harga saham terhadap harga saham pada perusahaan manufaktur yang terdaftar di Bursa Efek Indonesia. Penelitian ini merupakan pengembangan dari penelitian Lailia dan Suhermin (2017) dengan perbedaan sebagai berikut :

1. Penambahan variabel independen yaitu struktur aktiva karena struktur aktiva memiliki pengaruh langsung yang berlawanan dengan harga saham. Semakin naik struktur aktiva berarti aktiva tetap yang dimiliki perusahaan akan meningkat yang berakibat modal kerja dan kemampuan dari perusahaan untuk memenuhi kewajiban perusahaan yang akan jatuh tempo menurun, sehingga perusahaan akan memerlukan modal dari saham, sehingga harga saham akan turun ( Mahapsari danTaman, 2013).

2. Objek penelitian ini menggunakan perusahaan sektor manufaktur yang terdaftar di Bursa Efek Indonesia (BEI) selama periode 2014 - 2016. Karena perusahaan manufaktur memiliki peranan penting bagi perekonomian Indonesia karena lebih produktif dan memberikan efek berantai yang luas. Industri manufaktur nasional menunjukkan kinerja yang semakin agresif, dengan peningkatan pada ekspansi dan penyerapan tenaga kerja.

Berdasarkan latar belakang di atas dan penelitian terdahulu, maka penulis termotivasi dan ingin mengembangkan kembali penelitian tersebut dengan judul "Pengaruh Struktur Modal, Profitabilitas, dan Struktur Aktiva Terhadap Harga Saham Pada Perusahaan Manufaktur Yang Terdaftar di Bursa Efek Indonesia ".

\section{Tinjauan Literatur dan Pengembangan Hipotesis}

\section{Teori Agensi}

Teori agensi (agency theory) merupakan salah satu aliran riset akuntansi terpenting dewasa ini. Asumsinya adalah individu bertindak demi kepentingannya sendiri. Asumsi lainnya menyebutkan bahwa entitas merupakan tempat atau titik pertemuan bagi berbagai jenis hubungan kontraktual yang terjadi antara manajemen, pemilik, kreditor, dan pemerintah. Oleh karena itu, teori agensi berfokus pada biaya biaya pemantauan dan penyelenggaraan hubungan keagenan antara berbagai pihak. Hubungan keagenan antar berbagai pihak tersebut banyak ditentukan berdasarkan angka-angka akuntansi yang mencakup perjanjian pinjaman, kompensasi manajemen, kontrak kontrak, dan ukuran perusahaan. Perjanjian pinjaman seringkali menentukan tingkat rasio seperti rasio utang terhadap ekuitas dan pelanggaran terhadap tingkat rasio maksimum tersebut akan menyebabkan perusahaan mengalami 
kesulitan teknis. Semakin dekat batasan utang terhadap ekuitas, semakin mungkin manajemen akan memilih alternatif akuntansi yang akan meningkatkan income. Dalam hal kontrak kompensasi manajemen, manajemen berupaya memilih metode yang meningkatkan income dan juga bonus. Oleh karena itu, pemilihan metode akuntansi oleh perusahaan dipengaruhi oleh efek metode akuntansi tersebut terhadap kontrak keagenan (Bastian, 2006).

\section{Teori Signal}

Menurut Wijaya (2012) dalam Pangemanan dan Maramis (2017), teori signal menekankan kepada pentingnya informasi yang dikeluarkan oleh perusahaan terhadap keputusan investasi pihak di luar perusahaan. Informasi merupakan unsur penting bagi investor dan pelaku bisnis karena informasi pada hakekatnya menyajikan keterangan, catatan atau gambaran baik untuk keadaan masa lalu, saat ini maupun keadaan masa yang akan datang bagi kelangsungan hidup suatu perusahaan dan bagaimana pasaran efeknya. Informasi yang lengkap, relevan, akurat dan tepat waktu sangat diperlukan oleh investor di pasar modal sebagai alat analisis untuk mengambil keputusan investasi.

\section{Struktur Modal}

Menurut Harjito dan Martono (2012), struktur modal (capital structure) adalah perbandingan atau imbangan pendanaan jangka panjang perusahaan yang ditunjukkan oleh perbandingan hutang jangka panjang tehadap modal sendiri. Teori struktur modal mengasumsikan bahwa perubahan struktur modal berasal dari penerbitan obligasi dan pembelian kembali saham biasa atau penerbitan saham baru. Berikut adalah beberapa pendekatan teori struktur modal menurut Husnan dan Pudjiastuti (2015).

1. Pendekatan tradisional

Pendekatan tradisional memperhitungkan tidak adanya pajak melalui perubahan struktur modal dengan memaksimalkan penggunaan hutang jangka panjang dan meminimalisasikan penggunaan modal sendiri (laba ditahan dan saham).

2. Pendekatan Modigliani dan Miller (MM)

MM menunjukkan bahwa pendekatan tradisional adalah tidak benar yang memungkinkan munculnya arbitrage yang membuat harga saham (atau nilai perusahaan) pada perusahaan yang tidak menggunakan hutang pada akhirnya mendukung pendekatan tradisional. Dalam keadaan ketika pasar modal sempurna dan memperhitungkan adanya pajak, keputusan pendanaan menjadi relevan.

3. Pendekatan packing order theory

Pendekatan ini menjelaskan alasan perusahaan dalam menentukan hirarki sumber dana yang paling disukai. Teori ini mendasarkan atas informasi asimetrik yang menunjukkan manajemen mempunyai informasi yang lebih banyak daripada pemodal publik. Secara ringkas teori packing order dijelaskan sebagai berikut.

a. Perusahan lebih menyukai pendaan internal.

b. Perusahaan akan berusaha menyesuaikan rasio pembagian dividen dengan kesempatan investasi yang dihadapi.

c. Pembayaran dividen yang cenderung konstan dan fluktuasi laba yang diperoleh mengakibatkan dana internal kadang kadang berlebih ataupun kurang untuk investasi.

d. Perusahaan akan menerbitkan sekuritas yang paling aman terlebih dahulu. Penerbitan sekuritas dimulai dari penerbitan obligasi yang dapat dikonversikan menjadi modal sendiri yang pada akhirnya menerbitkan saham baru. 


\section{Profitabilitas}

Menurut Agustini dan Budiyanto (2015), profitabilitas merupakan kemampuan perusahaan untuk memperoleh laba dari kegiatan bisnis yang di lakukannya. Perusahaan yang memiliki profitabilitas yang tinggi cenderung menggunakan hutang yang relatif kecil karena laba ditahan yang tinggi sudah mencukupi untuk membiayai seberapa besar kebutuhan dana perusahaan. Menurut Brigham dan Houston (2011: 161), perusahaan dengan tingkat pengembalian yang tinggi atas investasi menggunakan utang yang relatif kecil karna tingkat pengembalian yang tinggi memungkinkan perusahaan untuk membiayai sebagian besar pendanaan internal. Perusahaan yang mempunyai profit tinggi, akan menggunakan hutang dalam jumlah rendah. Perusahaan yang mendapatkan laba ditahan yang besar akan menggunakan laba ditahan sebelum memutuskan untuk menggunakan hutang.

\section{Struktur Aktiva}

Menurut Syamsudin (2009:9) dalam Thausyah dan Suwitho (2015), struktur aktiva merupakan penentuan berapa besar alokasi dana untuk masing-masing komponen aktiva, baik aktiva lancar maupun aktiva tetap. Total aktiva adalah jumlah keseluruhan dari aset yang dimiliki oleh perusahaan yang terdiri dari aktiva lancar, aktiva tetap, dan aktiva lainnya yang apabila dijumlahkan nilainya seimbang dengan total kewajiban dan ekuitas (Margaretha, 2003:108).

\section{Harga Saham}

Menurut Sambelay, et.al (2017), harga saham merupakan salah satu indicator pengelolaan perusahaan. Keberhasilan keuntungan akan memberikan keputusan bagi investor yang rasional. Harga saham yang cukup tinggi akan memberikan keuntungan, yaitu berupa capital gain dan citra yang lebih baik bagi perusahaan sehingga memudahkan bagi manajemen untuk mendapatkan dana dari luar perusahaan. Menurut Sunariyah (2011:127) ada 3 (tiga) jenis harga saham yaitu harga nominal yang merupakan nilai yang ditetapkan oleh emiten untuk menilai setiap lembar saham yang dikeluarkannya tergantung dari keinginan perusahaan, harga perdana yang merupakan harga sebelum harga saham dicatat di bursa yang tergantung pada persetujuan antara emiten dan penjamin emisi, dan harga pasar yang merupakan harga jual saham antara investor yang satu dengan investor lainnya setelah dicatat di bursa yang tergantung pada kekuatan permintaan dan penawaran dipasar sekunder.

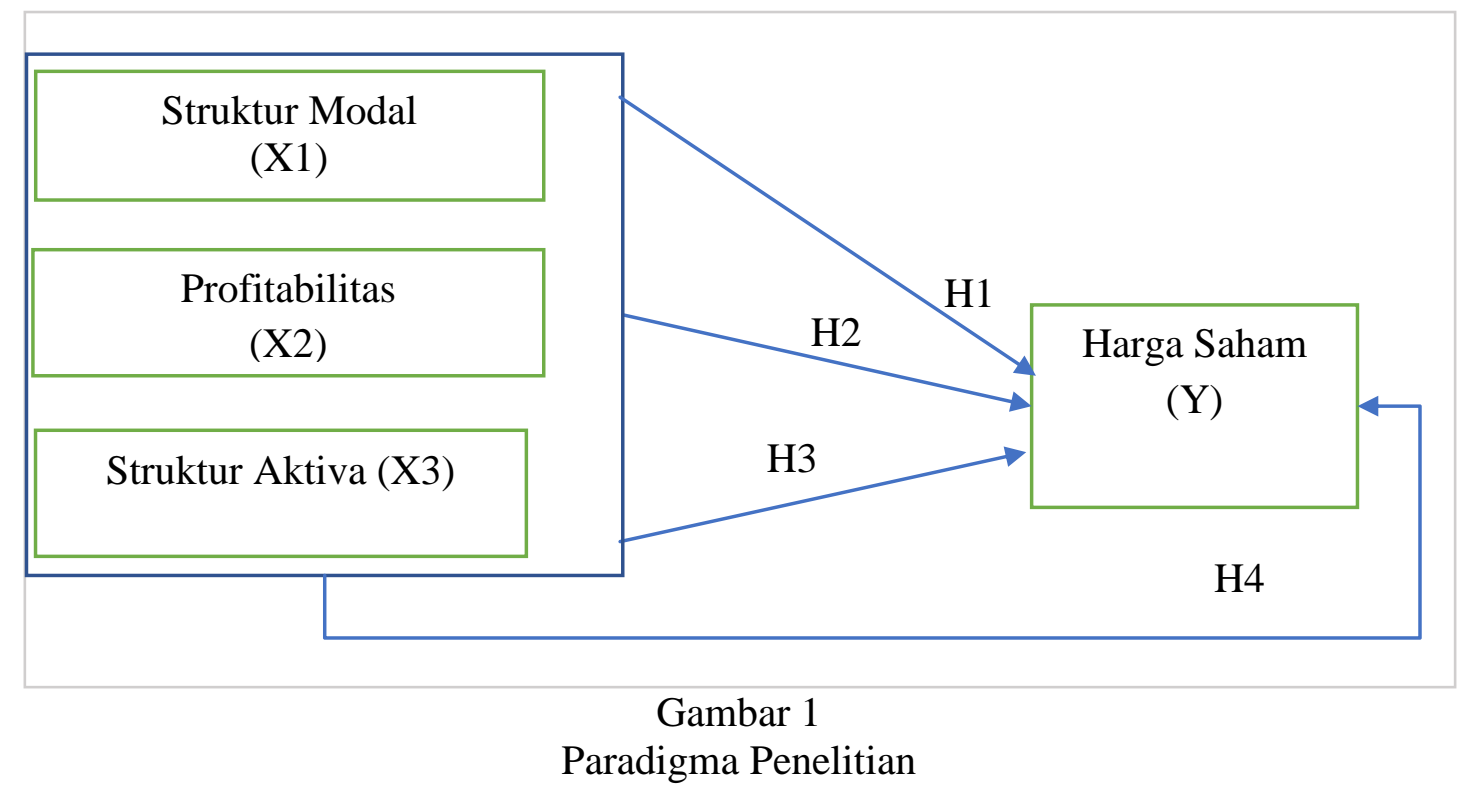




\section{Struktur Modal Terhadap Harga Saham}

Menurut Purnamawati (2016), penggunaan dana perusahaan berasal dari struktur modal yang dimiliki oleh perusahaan yaitu utang jangka panjang dan moal yang bersumber dari ekuitas. Investor akan melihat seberapa besar modal yang dibiayai oleh mereka pada perusahaan untuk menghasilkan laba bersih. Dengan semakin tingginya DER mengindikasikan bahwa struktur modal perusahaan lebih banyak memanfaatkan dana eksternal yang berasal dari kreditur untuk menghasilkan laba yang meningkatkan harga saham. Semakin tinggi penggunaan hutang maka bunga hutang yang dibayarkan dapat mengurangi pajak yang dibayar oleh perusahaan. Penghematan pajak ini merupakan keuntungan bagi pemegang saham yang mempengaruhi peningkatan harga saham (Harjito dan Martono dan Harjito, 2012). Lailia dan Suhermin (2017) dalam penelitiannya menunjukkan struktur modal berpengaruh positif tehadap harga saham.

$\mathrm{H}_{1}$ : Struktur modal berpengaruh positif terhadap harga saham

\section{Profitabilitas terhadap Harga Saham}

Menurut Kartikasari (2011: 40) dalam Lailia dan Suhermin (2017), profitabilitas adalah rasio yang menunjukkan hasil akhir dari sejumlah kebijakan dan keputusan. Rasio ini juga menunjukkan kemampuan modal yang diinvestasikan dalam keseluruhan aktiva untuk menghasilkan keuntungan neto. Informasi ini berguna dalam perumusan pertimbangan tentang efektivitas perusahaan dalam memanfaatkan sumberdaya. Diasumsikan bahwa investor tidak menyukai resiko sehingga menginginkan tingkat laba yang stabil. Tapi profitabilitas yang tinggi juga dapat meningkatkan biaya politis yang harus ditanggung oleh perusahaan, khususnya pajak. Menurut Kasmir (2013:203), semakin besar profitabilitas menunjukkan kinerja perusahaan yang semakin baik karena memberikan hasil (return) yang semakin besar. Dengan adanya hasil (return) yang semakin besar maka akan menarik minat investor untuk menanamkan modalnya pada perusahaan tersebut sehingga selanjutnya akan berdampak pada kenaikkan harga saham karena bertambahnya permintaan terhadap saham perusahaan tersebut. Lailia dan Suhermin (2017) dalam penelitiannya menunjukkan profitabilitas berpengaruh positif dan signifikan tehadap harga saham.

$\mathrm{H}_{2}$ : Profitabilitas berpengaruh positif terhadap harga saham

\section{Struktur Aktiva terhadap Harga Saham}

Menurut Syamsudin (2007:9) dalam Agustini dan Budiyanto (2015), struktur aset perusahaan memiliki peranan penting dalam menentukan pembiayaan perusahaan yang memiliki aktiva tetap jangka panjang tinggi, karena permintaan akan produk perusahaan yang tinggi akan banyak menggunakan utang aset jangka panjang. Apabila perusahaan memiliki asset yang tinggi maka kecil kemungkinan asimetri informasi akan terjadi karena penilaian asetnya lebih mudah karena perusahaan memiliki jaminan yang memadai bagi investor, sehingga meningkatkan keinginan investor untuk berinvestasi yang akan membuat harga saham meningkat. Menurut Mahapsari dan Taman (2013) dalam penelitiannya menunjukkan hasil penelitian terdapat pengaruh negatif struktur aktiva terhadap harga saham.

$\mathrm{H}_{3}$ : Struktur aktiva berpengaruh positif terhadap harga saham.

\section{Metode Penelitian}

\section{Metode Pengumpulan Data}

Penelitian ini menggunakan data sekunder yaitu data yang diperoleh dari laporan keuangan perusahaan manufaktur yang terdaftar di Bursa Efek Indonesia (BEI) selama periode 2014 - 2016. Seluruh sumber data diperoleh melalui studi pustaka berdasarkan akses langsung ke website resmi Bursa Efek Indonesia yaitu www.idx.co.id. 


\section{Populasi dan Sampel Penelitian}

Populasi dalam penelitian ini adalah seluruh perusahaan yang terdaftar di Bursa Efek Indonesia (BEI) selama periode 2014 - 2016. Dan sampel dalam penelitian ini adalah perusahaan manufaktur yang terdaftar di Bursa Efek Indonesia (BEI) selama periode 2014 2016. Teknik pengambilan sampel yang digunakan dalam penelitian ini adalah purposive sampling dengan kriteria pemilihan sampel sebagai berikut.

1. Perusahaan manufaktur yang terdaftar di Bursa Efek Indonesia pada tahun 2014 2016

2. Perusahaan manufaktur telah mempublikasikan laporan keuangan yang telah diaudit selama periode $2014-2016$

3. Laporan keuangan menyajikan mata uang rupiah dalam pelaporan keuangan

4. Perusahaan manufaktur yang tidak mengalami kerugian selama periode $2014-2016$

\section{Operasionalisasi Variabel}

\section{Struktur Modal}

Struktur modal dalam penelitian ini direplikasi dari Lailia dan Suhermin (2017) dengan proksi debt to equity ratio (DER) yang mencerminkan perbandingan antara total debt (total hutang) dan total shareholder's equity (total modal). Debt to equity ratio merupakan kemampuan yang mengukur besarnya hutang yang dimiliki perusahaan dengan modal sendiri. Rasio ini menunjukkan berapa besar hutang perusahaan yang mampu dijamin oleh equity yang dimiliki oleh perusahaan. Skala yang digunakan dalam pengukuran ini adalah skala rasio.

\section{Debt to Equity Ratio = Total Hutang / Total Modal}

\section{Profitabilitas}

Menurut Lailia dan Suhermin (2017), profitabilitas merupakan kemampuan suatu perusahaan dalam menghasilkan laba yang berkaitan dengan penjualan, aset, dan modal perusahaan. Profitabilitas diukur dengan return on assets (ROA) yang menunjukkan kemampuan perusahaan menghasilkan laba dari aset yang dipergunakan. Skala yang digunakan dalam pengukuran ini adalah skala rasio.

Return On Assets = Laba Setelah Pajak / Total Aset

\section{Struktur Aktiva}

Menurut Agustini dan Budiyanto (2015), struktur aktiva yaitu penentuan seberapa besar jumlah alokasi untuk masing-masing komponen aktiva, baik aktiva tetap maupun aktiva lancar. Ukhriyawati, et.al (2017) dalam pengukurannya mengukur struktur aktiva menggunakan Tangibility Asset Ratio. Skala yang digunakan dalam pengukuran ini adalah skala rasio.

Tangibility Asset Ratio $=$ Aset Tetap $/$ Total Aset

\section{Metode Analisis Data}

Menurut Ghozali (2016), statistik deskriptif bertujuan untuk memberikan gambaran atau deskripsi dari data yang di analisis meliputi nilai minimum, nilai maksimum, rata rata (mean), standar deviasi, varian, maksimum, minimum, sum, range, kurtosis dan skewness (kemencengan distribusi). Uji normalitas bertujuan untuk meguji apakah sebuah model regresi, variabel terikat, variabel bebas, atau keduanya mempunyai distribusi normal atau tidak. Uji multikolinieritas merupakan salah satu uji asumsi klasik yang bertujuan untuk menguji apakah model regresi yang telah ditemukan terdapat korelasi antar variable-variable independen dalam suatu penelitian. Uji heteroskedastisitas merupakan uji asumsi klasik yang 
bertujuan untuk menguji apakah dalam model, regresi terjadi kesamaan atau tidak kesamaan variance dari residual satu pengamatan ke pengamatan lain. Uji autokorelasi merupakan uji asumsi klasik yang bertujuan untuk menguji apakah dalam model regresi linear ada korelasi antara kesalahan pengganggu (error) pada periode $\mathrm{t}$ dengan kesalahan pengganggu (error) pada periode t-1 (sebelumnya).

Ghozali (2016) menyatakan uji korelasi bermanfaat untuk mengukur kekuatan hubungan antara dua variabel (kadang lebih dari dua variable) dengan skala-skala tertentu. Uji koefisien determinasi digunakan untuk mengetahui seberapa jauh kemampuan model dalam menerangkan variasi variable dependen. Uji F digunakan untuk mengetahui apakah secara keseluruhan semua variable independen berpengaruh terhadap variable dependen. Uji hipotesis merupakan metode pengambilan keputusan yang didasarkan pada analisis data, baik dari percobaan yang terkontrol, maupun dari observasi (tidak terkontrol). Analisis regresi berganda digunakan untuk mengukur pengaruh antara lebih dari satu variabel independen terhadap variabel dependen. Adapun persamaan regresi linear berganda secara matematis adalah sebagai berikut.

\begin{tabular}{ll}
\hline $\mathrm{SP}=\alpha+\mathrm{DER} \beta_{1}+\mathrm{ROA} \beta_{2}+\mathrm{TAR} \beta_{4}+\mathrm{e}$ \\
\hline Dimana : & $:$ Harga Saham \\
SP & $:$ Struktur Modal (debt to equity ratio) \\
DER & : Profitabilitas (return on asset) \\
ROA & : Struktur Aktiva (Tangibility Asset Ratio) \\
TAR & $:$ Konstanta \\
$\alpha$ & $:$ Koefisien regresi \\
$\beta_{1}$ sampai $\beta_{3}$ & $:$ Error \\
$\mathrm{e}$ &
\end{tabular}

\section{Hasil Penelitian dan Pembahasan}

\section{Hasil Kriteria Pemilihan Sampel}

Data yang digunakan penulis dalam penelitian ini menggunakan data sekunder yaitu data yang diperoleh dari laporan keuangan perusahaan manufaktur yang terdaftar di Bursa Efek Indonesia (BEI) selama periode 2014 - 2016 dengan hasil kriteria pemilihan sampel penelitian sebagai berikut.

Tabel 1

Kriteria Pemilihan Sampel

\begin{tabular}{|c|l|c|}
\hline 1 & Total perusahaan manufaktur yang terdafter di BEI & 144 \\
\hline 2 & $\begin{array}{l}\text { Perusahaan yang tidak terdaftar di BEI secara konsisten selama } \\
\text { periode 2014 - 2016 }\end{array}$ & $(3)$ \\
\hline 3 & $\begin{array}{l}\text { Tidak melakukan audit pada laporan keuangan selama priode 2014 - } \\
2016\end{array}$ & $(11)$ \\
\hline 4 & Tidak menyajikan laporan dalam mata uang rupiah & $(24)$ \\
\hline 5 & Tidak mengalami kerugian selama periode 2014-2016 & $(44)$ \\
\hline 6 & Total sampel sebelum outlier (3 tahun x 62) & 186 \\
\hline 7 & Data outlier & $(2)$ \\
\hline 8 & Total sampel setelah outlier & 184 \\
\hline
\end{tabular}




\section{Statistik Deskriptif}

Tabel 2

Hasil Statistik Deskriptif

\begin{tabular}{|l|r|r|r|r|}
\hline \multicolumn{1}{|c|}{ Variabel } & \multicolumn{1}{|c|}{ Minimum } & Maksimum & \multicolumn{1}{c|}{ Rata-rata } & \multicolumn{1}{c|}{$\begin{array}{l}\text { Deviasi } \\
\text { Standar }\end{array}$} \\
\hline Harga Saham & 50 & 94.000 & 5.008 & 11.941 \\
\hline Struktur Modal & 0,0770 & 5,2004 & 0,81431 & 0,79478 \\
\hline Profitabilitas & 0,0004 & 0,4977 & 0,09380 & 0,08953 \\
\hline Struktur Aktiva & 0,0006 & 0,8081 & 0,42490 & 0,16539 \\
\hline
\end{tabular}

Struktur modal memiliki rata- rata (mean) sebesar 0.814 yang artinya seluruh perusahaan yang terdaftar di Bursa Efek Indonesia (BEI) selama periode 2014 - 2016 memiliki rata rata struktur modal sebesar $81.4 \%$. Nilai minimum struktur modal adalah 0.077 yang dimiliki oleh perusahaan Semen Baturaja Persero Tbk pada tahun 2014 dan nilai maksimum sturktur modal adalah 5.2 yang dimiliki oleh perusahaan Jembo Cable Company Tbk pada tahun 2014 dengan standar deviasi sebesar 79.47\%. Hasil dari standar deviasi menunjukkan angka yang lebih kecil dari rata rata (mean).

Profitabilitas memiliki rata rata (mean) sebesar 0.093 yang artinya seluruh perusahaan yang terdaftar di Bursa Efek Indonesia (BEI) selama periode 2014 - 2016 memiliki rata rata profitabilitas sebesar 9.3\%. Nilai minimum profitabilitas 0.0004 yang dimiliki oleh perusahaan Star Petrochem Tbk pada tahun 2015 dan nilai maksimum profitabilitas 0.4977 yang dimiliki oleh perusahaan Arwana Citra Mulia Tbk pada tahun 2015 dengan standar deviasi $8.95 \%$. Hasil dari standar deviasi menunjukkan angka yang lebih kecil dari rata rata (mean), hal tersebut membuktikan bahwa tidak ada data yang nominalnya lebih besar dari profitabilitas terendah sampai profitabilitas tertinggi.

Struktur Aktiva memiliki rata rata (mean) sebesar 0.4249 yang artinya seluruh perusahaan yang terdaftar di Bursa Efek Indonesia (BEI) selama periode 2014 - 2016 memiliki rata rata struktur aktiva sebesar 42.5\%. Nilai minimum struktur aktiva 0.0006 yang dimiliki oleh perusahaan Argha Karya Prima Industry Tbk pada tahun 2014 dan nilai maksimum struktur aktiva 0.8081 yang dimiliki oleh perusahaan Semen Baturaja Persero Tbk pada tahun 2016 dengan standar deviasi $16.53 \%$.

Harga saham memiliki rata rata (mean) sebesar Rp 5.008. Nilai minimum harga saham sebesar Rp 50 yang dimiliki oleh perusahaan Indo Acitama Tbk pada tahun 2014, 2015, 2016 dan perusahaan Star Petrochem Tbk pada tahun 2014 dan 2015 dan nilai maksimum harga saham sebesar Rp 94.000 yang dimiliki oleh perusahaan Hanjaya Mandala Sampoerna Tbk pada tahun 2015. Hal ini menunjukkan bahwa perusahaan sampel memiliki perbandingan harga saham yang beredar paling kecil adalah Rp.50 dan paling besar Rp 94.000 dengan standar deviasi Rp 11.941 yang menunjukkan variasi yang terdapat dalam harga saham.

\section{Uji Normalitas}

Tabel 3

Hasil Uji Normalitas

\begin{tabular}{|c|c|c|}
\hline Model & Asymp. Sig. & Kesimpulan \\
\hline 1 & 0,066 & Data terdistribusi normal \\
\hline
\end{tabular}


Berdasarkan hasil output di tabel 3 menunjukkan bahwa sig sebesar 0.066 lebih besar dari 0.05. Dari hasil ini dapat disimpulkan bahwa data struktur modal, profitabilitas, struktur aktiva, dan harga saham berdistribusi normal.

\section{Uji Multikolinearitas}

Tabel 4

Hasil Uji Multikolinearitas

\begin{tabular}{|c|c|c|c|}
\hline $\begin{array}{c}\text { Variabel } \\
\text { Independen }\end{array}$ & Tolerance & VIF & Kesimpulan \\
\hline Struktur Modal & 0,927 & 1,079 & Tidak terdapat multikolinearitas \\
\hline Profitabilitas & 0,915 & 1,093 & Tidak terdapat multikolinearitas \\
\hline Struktur Aktiva & 0,987 & 1,013 & Tidak terdapat multikolinearitas \\
\hline
\end{tabular}

Berdasarkan hasil uji multikolinearitas di tabel 4 pada struktur modal, profitabilitas, dan struktur aktiva menunjukkan bahwa nilai tolerance $>0,1$ dan VIF $<10$. Dari hasil ini dapat disimpulkan bahwa data struktur modal, profitabilitas, dan struktur aktiva tidak mengalami masalah multikolinearitas.

\section{Uji Autokorelasi}

Tabel 5

Hasil Uji Autokorelasi

\begin{tabular}{|r|c|}
\hline Durbin Watson & Kesimpulan \\
\hline 0,730 & Tidak terdapat autokorelasi \\
\hline
\end{tabular}

Berdasarkan hasil uji autokorelasi di tabel 5 menunjukkan angka Durbin-Watson sebesar 1.931 dan nilai dU untuk jumlah sampel 184 setelah dilakukan uji outlier dengan 3 variabel bebas adalah 1.792. Maka nilai 4-dU adalah 2.208, sehingga hasil uji autokorelasi $\mathrm{dU}<\mathrm{d}<(4-\mathrm{dU})$ yaitu $1,792<1,931<2.208$ dan dapat disimpulkan bahwa tidak terjadi autokorelasi positif maupun negatif.

\section{Uji Heteroskedastisitas}

\section{Tabel 6}

Hasil Uji Heteroskedastisitas

\begin{tabular}{|l|l|l|}
\hline \multicolumn{1}{|c|}{ Variabel } & Sig. & Kesimpulan \\
\hline Struktur Modal & 0,074 & Tidak terdapat heteroskedastisitas \\
\hline Profitabilitas & 0,794 & Tidak terdapat heteroskedastisitas \\
\hline Struktur Aktiva & 0,798 & Tidak terdapat heteroskedastisitas \\
\hline
\end{tabular}

Berdasarkan hasil pengujian heteroskedastisitas pada tabel 6 menunjukkan bahwa struktur modal memiliki nilai signifikansi sebesar 0.074, profitabilitas memiliki nilai signifikansi 0.794 , dan struktur aktiva memiliki nilai signifikansi 0.798 yang lebih besar dari 0.05. Dengan demikian, dapat disimpulkan bahwa data penelitian tidak megalami masalah heteroskedastisitas.

\section{Uji Hipotesis}

Uji Korelasi dan Koefisien Determinasi

Tabel 7 
Hasil Uji Korelasi dan Koefisien Determinasi

\begin{tabular}{|c|c|c|}
\hline Model & $\mathrm{R}$ & Adjusted R-Square \\
\hline 1 & 0,604 & 0,365 \\
\hline
\end{tabular}

Berdasarkan hasil pengujian korelasi dan koefisien determinasi pada tabel 7 , mencerminkan tingkat keeratan hubungan variable struktur modal, profitabilitas, dan struktur aktiva terhadap harga saham. Nilai koefisien korelasi (R) yaitu sebesar 0.604 atau $60.4 \%$ yang berarti bahwa hubungan antara struktur modal, profitabilitas, dan struktur aktiva terhadap harga saham, mempunyai hubungan yang erat. Nilai dari koefisien determinasi $\left(\mathrm{R}^{2}\right)$ pada sebesar 0.354 atau $35.4 \%$ yang berarti bahwa struktur modal, profitabilitas, dan struktur aktiva secara simultan mempunyai pengaruh terhadap harga saham. Sedangkan sisanya sebesar $64.6 \%$ di distribusikan oleh variabel lain yang tidak dimasukkan dalam model regresi pada penelitian ini.

\section{Uji F}

\section{Tabel 8}

Hasil Uji F

\begin{tabular}{|r|r|rr|}
\hline Model & F & \multicolumn{2}{|c|}{ Sig. } \\
\hline & 1 & 34,486 & 0,000 \\
\hline
\end{tabular}

Berdasarkan hasil uji signifikan simultan pada tabel 8, nilai signifikan yang diperoleh sebesar 0,000 yang lebih kecil dari 0,05. Maka dapat disimpulkan bahwa $\mathrm{H}_{0}$ ditolak dan $\mathrm{H}_{\mathrm{a}}$ diterima, yang berarti model data fit dan baik digunakan dalam penelitian.

\section{Uji T}

Tabel 9

Hasil Uji T

\begin{tabular}{|l|r|r|r|l|}
\hline \multicolumn{1}{|c|}{ Variabel } & Koefisien & \multicolumn{1}{c|}{ T } & \multicolumn{1}{c|}{ Sig. } & \multicolumn{1}{c|}{ Keputusan } \\
\hline Konstanta & 4,212 & 29,229 & 0,000 & \\
\hline Struktur Modal & 0,206 & 1,625 & 0,106 & Tidak pengaruh \\
\hline Profitabilitas & 0,813 & 10,099 & 0,000 & Pengaruh Positif \\
\hline Struktur Aktiva & 0,125 & 0,784 & 0,434 & Tidak pengaruh \\
\hline
\end{tabular}

Berdasarkan hasil uji t pada tabel 9 dirumuskan persamaan regresi sebagai berikut. $\mathrm{SP}=4.212+$ DER $0.206+$ ROA $0.813+$ TAR 0.125

Dari persamaan diatas, dapat diketahui bahwa koefisien konstanta adalah sebesar 4.212. Hal ini menunjukkan bahwa apabila struktur modal, profitabilitas, dan struktur aktiva sama dengan nol (0), maka besarnya harga saham adalah sebesar 4.212. Nilai koefisien regresi dari struktur modal menunjukkan nilai positif yang berarti adanya hubungan yang searah antara struktur modal dengan harga saham. Besarnya koefisien regresi struktur modal adalah sebesar 0.206. Nilai koefisien regresi tersebut menunjukkan bahwa jika struktur modal mengalami kenaikan sebesar satu kesatuan maka nilai harga saham akan mengalami peningkatan sebesar 0,206, dengan asumsi pada saat yang bersamaan variabel independen lain yang mempengaruhi harga saham dalam keadaan konstan.

Nilai koefisien regresi profitabilitas menunjukkan nilai positif yang berarti adanya hubungan yang searah antara profitabilitas dengan harga saham. Besarnya koefisien regresi profitabilitas adalah sebesar 0.813. Nilai koefisien regresi tersebut menunjukkan bahwa jika profitabilitas mengalami kenaikan sebesar satu kesatuan maka nilai harga saham akan mengalami peningkatan sebesar 0.813 dengan asumsi pada saat yang bersamaan variabel independen lain yang mempengaruhi harga saham dalam keadaan konstan. Nilai koefisien 
regresi struktur aktiva menunjukkan nilai positif yang berarti adanya hubungan yang searah antara struktur aktiva dengan harga saham. Besarnya koefisien regresi struktur aktiva adalah sebesar 0.125. Nilai koefisien regresi tersebut menunjukkan bahwa jika struktur aktiva mengalami kenaikan sebesar satu kesatuan maka harga saham akan mengalami peningkatan sebesar 0.125 dengan asumsi pada saat yang bersamaan variabel independen lain yang mempengaruhi harga saham dalam keadaan konstan.

Berdasarkan hasil uji t pada tabel 9, dapat dilihat bahwa tingkat signifikansi yang diperoleh pada struktur modal sebesar 0.106 yang lebih besar dari 0.05 . Koefisen regresi struktur modal yang diperoleh bernilai positif sehingga dapat disimpulkan bahwa struktur modal tidak berpengaruh terhadap harga saham. Tingkat signifikansi profitabilitas yang diperoleh sebesar 0,000 dimana nilai tersebut lebih kecil dari 0.05. Koefisien regresi profitabilitas yang diperoleh menunjukkan nilai positif sehingga dapat disimpulkan bahwa profitabilitas mempunyai pengaruh positif dan signifikan terhadap harga saham. Tingkat signifikansi struktur aktiva yang diperoleh sebesar 0,434 yang lebih besar dari 0.05 . Koefisien regresi struktur aktiva yang diperoleh menunjukkan nilai positif sehingga dapat disimpulkan bahwa struktur aktiva tidak berpengaruh terhadap harga saham.

Struktur modal tidak berpengaruh terhadap harga saham dikarenakan besar kecilnya hutang tidak menunjukkan kinerja perusahaan yang baik atau buruk sehingga hal ini tidak berdampak pada perubahan harga saham. Profitabilitas berpengaruh positif terhadap harga saham dikarenakan investor meyakini bahwa dengan semakin meningkatnya tingkat pengembalian atas aktiva menunjukkan kinerja perusahaan yang semakin baik dalam mengelola aset yang mereka miliki untuk menghasilkan laba, sehingga dengan adanya hasil yang semakin besar maka akan menarik minat investor untuk menanamkan modalnya pada perusahaan tersebut yang selanjutnya akan berdampak pada kenaikan harga saham karena bertambahnya permintaan terhadap harga saham perusahaan tersebut. Struktur aktiva tidak berpengaruh terhadap harga saham dikarenakan aset tetap perusahaan yang jarang mengalami perubahan dan dalam pengelolaannya tidak berdampak besar dalam peningkatan laba bersih perusahaan yang tidak mempengaruhi perubahan harga saham.

\section{Simpulan dan Saran}

Berdasarkan hasil analisis data dan pembahasan yang telah dikemukakan, maka penelitian ini menghasilkan simpulan sebagai berikut :

1. Struktur modal tidak berpengaruh terhadap harga saham. Hasil penelitian ini tidak konsisten dengan penelitian Pangemanan dan Maramis (2017) dan konsisten dengan penelitian Lailia dan Suhermin (2017).

2. Profitabilitas berpengaruh positif terhadap harga saham. Hasil penelitian ini konsisten dengan penelititan Oktaviani dan Komalasarai (2017) serta Indrawati dan Suprihhadi (2016).

3. Struktur aktiva tidak berpengaruh terhadap harga saham perusahaan. Hasil penelitian ini konsisten dengan penelititan Mahapsari dan Taman (2013).

Berdasarkan simpulan yang telah disebutkan di atas, maka saran yang dapat diberikan bagi peneliti selanjutnya adalah :

1. Penelitian berikutnya dapat menambahkan faktor-faktor keuangan internal perusahaan yang mempengaruhi harga saham selain struktur modal, profitabilitas, dan struktur aktiva seperti pertumbuhan penjualan dan pertumbuhan aliran kas bersih sehingga dapat menggambarkan kondisi keuangan perusahaan yang sesungguhnya yang dapat mempengaruhi perubahan harga saham. 
2. Penelitian menggunakan periode waktu penelitian yang lebih lama minimal 5 tahun agar dapat menggeneralisasi hasil penelitian pada sector usaha perusahaan publik tertentu.

3. Objek penelitian perusahaan yang digunakan sebagai sampel dari berbagai sub sektor dan tidak terpaku pada seluruh perusahaan manufaktur, sehingga untuk penelitian selanjutnya dapat dikhususkan pembahasannya berdasarkan setiap sektor usaha yang hasilnya dapat diperbandingkan dari tahun ke tahun.

\section{DAFTAR PUSTAKA}

Agustini, T. dan Budiyanto. 2015. Pengaruh Struktur Aktiva, Profitabilitas, dan Ukuran Perusahaan Terhadap Struktur Modal. Jurnal Ilmu dan Riset Manajemen, Vol. 4, No. 8.

Bastian, Indra. S. A. 2006. Akuntansi Pendidikan. Yogyakarta : Erlangga.

Brigham, E. F., and J. F. Houston. 2011. Dasar-Dasar Manajemen Keuangan. Jakarta: Salemba Empat.

https://www.cnbcindonesia.com/market/20181231120250-17-48509/kinerja-ihsg-2018terburuk-dalam-3-tahun. Diakses pada tanggal 5 April 2019.

Ghozali, Imam. 2016. Aplikasi Analisis Multivariete Dengan Program IBM SPSS 23 (Edisi 8). Cetakan ke VIII. Semarang : Badan Penerbit Universitas Diponegoro.

Harjito, A. dan Martono. 2012. Manajemen Keuangan Edisi Kedua. Yogyakarta : Ekonisa. Husnan, Suad dan E. Pudjiastuti. (2015). Dasar-Dasar Manajemen Keuangan Edisi Ketujuh. Yogyakarta: UPP STIM YKPN.

Indrawati, S., dan H. Suprihhadi. 2016. Pengaruh Profitabilitas terhadap Harga Saham Emiten LQ45 yang Terdaftar di BEI. Jurnal Ilmu dan Riset Manajemen, Vol. 5, No.2.

Kartini dan T. Arianto. 2008. Struktur Kepemilikan, Profitabilitas, Pertumbuhan Aktiva, dan Ukuran Perusahaan terhadap Struktur Modal pada Perusahaan Manufaktur. Jurnal Keuangan dan Perbankan, Vol 12, No. 1.

Kasmir. 2013. Analisis Laporan Keuangan. Jakarta: Rajawali Pers.

Lailia, N., dan Suhermin. 2017. Pengaruh Struktur Modal, Profitabilitas, dan Kebijakan Dividen Terhadap Harga Saham Perusahaan Food and Beverage. Jurnal Ilmu dan Riset Menejemen, Vol. 6, No 9.

Mahapsari, N. R, dan A. Taman. 2013. Pengaruh Profitabilitas, Struktur Aktiva, dan Pertumbuhan Penjualan terhadap Harga Saham dengan Struktur Modal sebagai Variabel Intervening pada Perusahaan Manufaktur di Bursa Efek Indonesia. Jurnal Nominal, Vol. 3, No. 1.

Margaretha, Farah. 2003. Teori dan Aplikasi Manajemen Keuangan Investasi dan Sumber Dana Jangka Panjang. Jakarta : Grasindo.

Octaviani, Santi. dan Dahlia Komalasarai. 2017. Pengaruh Likuiditas, Profitabilitas, dan Solvabilitas terhadap Harga Saham (Studi Kasus pada Perusahaan Perbankan yang Terdaftar di Bursa Efek Indonesia). Jurnal Akuntansi, Vol. 3, No. 2.

Pangemanan, R., S., I., dan Maramis, J. 2017. Analisis Pengaruh Profitabilitas dan Struktur Modal terhadap Harga Saham pada Perusahaan Sub Sektor Pertambangan Minyak dan Gas yang Terdaftar di Bursa Efek Indonesia. Jurnal EMBA, Vol. 5, No.3.

Putrawan, P. W., N. K. Sinarwati, and I. G. A. Purnamawati. 2015. Pengaruh Investasi Aktiva Tetap, Likuiditas, Solvabilitas, Dan Modal Kerja Terhadap Profitabilitas Perusahaan Otomotif Dan Komponen Yang Terdaftar Di Bursa Efek Indonesia Tahun 2010- 
2013. Singaraja: Jurusan Akuntansi Program S1 Universitas Pendidikan Ganesha Singaraja.

Sambelay, J.J., P. V. Rate, dan D.N. Baramuli. 2017. Analisis Pengaruh Profitabilitas terhadap harga saham pada perusahaan yang terdaftar di LQ45 Periode 2012-2016. Jurnal EMBA: Jurnal Riset Ekonomi, Manajemen, Bisnis dan Akuntansi, Vol. 5, No. 2.

Sunariyah. 2011. Pengantar Pengetahuan Pasar Modal Edisi Keenam. Yogyakarta: UPP STIM YKPN.

Thausyah, Nudzunul Fiara, \& Suwitho, D. 2015. Pengaruh Pertumbuhan Penjualan, Struktur Aktiva, dan Profitabilitas Terhadap Struktur Modal. Jurnal Ilmu dan Riset Manajemen, Vol. 4, No. 9.

Ukhriyawati, Catur F, T. Ratnawati, dan S. Riyadi. 2017. The Influence of Asset Structure, Capital Structure, Risk Management and Good Corporate Governance on Financial Performance and Value of the Firm through Earnings and Free Cash Flow as an Intervening Variable in Banking Companies Listed in Indonesia Stock Exchange. International Journal of Business and Management, Vol. 12, No.8, ISSN 1833-3850, E-ISSN 1833-8119. 